УДК 159.922

doi: $10.15330 / p s .10 .1 .110-117$

Віктор Сімкар

Тернопільський національний педагогічний університеті

імені Володимира Гнатюка

sitkarv@gmail.com

\title{
ДІАГНОСТИКА РІВНЯ ДОМАГАНЬ І САМООЦІНКИ ШКОЛЯРІВ НА МЕЖІ ЕПОХИ ДИТИНСТВА ТА ПІДЛІТКОВОГО ВІКУ
}

В статті наголошується, щуо емпіричні дослідження різних аспектів дитинства формують думку про загальний фон сочіальної ситуації, яка впливає на розвиток особистості в підлітковому віці. Діагностика рівня домагань та самооцінки у школярів на межі дитинства та підліткового віку поповнює банк наукових даних про складну систему особистісного становлення, яке має необмежену множинність шляхів розвитку у напрямку поступового розширення можливостей особистості. На підставі наявного потенціалу визначається психосоціальний баланс в суспільстві, від якого залежать стійкість сочіальної системи $i$ траєкторія ї̈ розвитку в майбутньому.

У дослідженні виявлено, щчо у респондентів обох вибірок проявлясться нереалістичне, некритичне ставлення до власних можливостей, бо середній показник у них перевищує 90 балів. Проте показники висоти самооцінки - вже різні в обох групах обстежуваних.

Зокрема, за критерієм Стьюдента, не виявлено відмінностей між самооиінкою за такими показниками як: уміння багато чого робити своїми руками (показник 0,14), розум $і$ здібності $(0,58)$, впевненість у собі $(0,85)$ та авторитет в однолітків $(1,18)$. В отриманих результатах самооцінки за показниками зовнішність (2,82), здоров’я (3,2) та характер (5.44) між учнями ЗОШ № 9 та ЗОШ № 13 вже існують відмінності, бо вони перевищують табличний t-критерій, який дорівнює відповідно 1,98 (для 0,05) та 2,63 (для 0,01), Зауважимо, щзо в респондентів ЗОШ № 9 виявлено сильну ступінь розходження між самоочінкою та рівнем домагань за двома показниками, а саме: характер та впевненість у собі, де числові вираження рівня домагань є вищими від показників самооцінки. Це пояснюється тим, щзо соціальні та функціональні умови шкіл, в яких відбувається навчальна та інша діяльність учнів - різні.

Ключові слова: дитинство, підлітки, самооиінка, рівень домагань, особистість, діагностика, розвиток.

Постановка проблеми. Інформатизація та глобалізація сучасних суспільних процесів зумовлюють формування нового світогляду, стратегій життєдіяльності та більш глибокі пізнання самої особистості. Свого часу Джордж Келлі описав феномен, який він назвав онтологічною акселерацією: людина не залишається незмінною, вона змінюється, причому швидше, ніж психологи встигають модифікувати свої теорії і підходи. В результаті теорії описують вчорашню людину, а сьогоднішня виявляється за межами розуміння (Kelly, 1969). В історичній психології ця думка втілюється у розумінні того, що люди різних епох - це різні люди. Інакше кажучи, людство еволюціонує, а всі ми $є$ результатом та передумовою психоісторичного процесу. Людина як складова культури своїм життям і самоздійсненням задає рух потоку культури і сама в цьому потоці розвивається і змінюється [8, с. 6]. Особливо актуальним означене є у площині аналізу особливостей психічного розвитку в дитинстві та підлітковому віці.

Актуальність теми дослідження зумовлена тим, що учні четвертого та п’ятого класів є на межі, яка розділяє епоху дитинства від підліткового віку. Спираючись на наукові праці психологів (Д. Ельконін, В. Поліщук, М. Савчин, В. Татенко) зазначимо, що основними новоутвореннями підліткового віку $є:$ 1) виникнення почуття дорослості; 2) формування самооцінки і появи прагнення до самовиховання; 3) підкорення нормам колективного життя. 4) залежність від колективу референтної групи. Основою для їх формування і розвитку є спілкування [5; 7].

Самооцінка - центральний компонент Я-концепції особистості, який охоплює оцінку людиною себе, своїх можливостей і якостей та місця серед інших людей. Від самооцінки залежить самокритичність людини і вимогливість до себе. Вона є основою ставлення людини до своїх успіхів та невдач і вибору цілей певної складності, тобто рівня домагань. Самооцінка починає формуватися уже на ранніх етапах розвитку дитини під 
впливом оцінок іiі якостей дорослими. У процесі розвитку поступово зростає здатність дитини самостійно оцінювати свої якості і її самооцінка все менше залежить від оцінок оточуючих. Самооцінка людини не залишається весь час однаковою. Вона змінюється залежно від умов, у яких відбувається діяльність людини, і стабільності досягнутих успіхів [7, с. 313].

Рівень домагань особистості - це сукупність прагнень особистості досягнути цілей такого рівня складності, на який вона вважає себе здатною. Рівень домагань пов'язаний із самооцінкою особистості і формується у результаті суперечності двох тенденцій: бажання досягти успіху в діяльності і прагнення уникнути невдачі. Рівень домагань особистості може бути адекватним і неадекватним (заниженим або завищеним) можливостям людини. За адекватного рівня домагань особистості людина, правильно оцінюючи свої можливості, сповна використовує їх при виборі і вирішенні різних завдань. Занижений рівень домагань особистості негативно впливає на розвиток особистості: людина не повністю використовує свої можливості, залишається байдужою до досягнутих результатів. У школярів занижений рівень домагань особистості проявляється в нерозвиненості пізнавальних інтересів і заниженій мотивації навчання. Завищений рівень домагань особистості іноді стає причиною появи у людини афекту неадекватності, що призводить до конфліктів з іншими людьми. Рівень домагань особистості не є постійним протягом життя людини, а може змінюватися під впливом виховання [7, с. 302].

Аналіз останніх досліджень і публікацій. Сьогодні науковці (В. Колпаков, П. Лушин, I. Пригожин; D. Magnusson, L. Pervin ets.) в контексті стрімкого збільшення обсягів інформації, яка виступає інструментом особистісного зростання в сучасному суспільстві, розглядають особистість як відкриту динамічну систему, мета якої - це підтримання життєтворчості людини за посередництвом самоорганізації в єдності із навколишнім середовищем. Складна система особистісного становлення та самоорганізації має необмежену множинність шляхів розвитку (А. Богданов, В. Колпаков, А. Самарський та ін.) у напрямку поступового розширення можливостей особистості (векторів ідентичності) на підставі наявного потенціалу (А. Goodman, E. Payne; П. Лушин) [8, с. 50].

Теоретичні основи психосоціальної концепції розвитку закладено в працях Е. Еріксона. Епігенетичний принцип Е. Еріксон вважав універсальним, що діє як на онтогенетичному, так і на соціогенетичному рівнях, а отже, дозволяє розглядати ці дві лінії розвитку в їх органічному взаємозв'язку. В межах вікової періодизації, яку запропонував Е. Еріксон, життєвий цикл людини представляється у вигляді послідовності восьми вікових криз, кожну з яких можна розглядати як поворотну точку в процесі розвитку. В основі кожної кризи лежить конфлікт між позитивним, вітальним началом в людській природі i негативним, деструктивним началом в їх специфічних проявах, що характерні для даного віку. Розв'язання цих конфліктів визначається генетичними задатками, результатами попереднього розвитку та соціальним контекстом [1].

Статусно-рольова позиція індивіда в контактних співтовариствах відкритого типу здебільшого зумовлена особливостями його психосоціального розвитку на базових стадіях епігенетичного циклу. Зокрема, типовий профіль психосоціального розвитку неформальних лідерів в таких співтовариствах характеризується стійким позитивним розв'язком базових конфліктів перших чотирьох стадій епігенетичного циклу та особистісним структуруванням за принципом цілісності. В той же час стійке позитивне розв'язання базових конфліктів першої, третьої і четвертої стадій психосоціального розвитку мінімізує ймовірність потрапляння індивіда в нижній статусний шар неформальної інтрагрупової структури [1]. Співвідношенням рівнів дитячої та інституційної вітальностей визначається психосоціальний баланс в суспільстві, від якого залежать стійкість соціальної системи і траєкторія ії розвитку. Найбільш репрезентативною в цьому плані є підлітковий вік, який $\epsilon$ п'ятою стадією вікового розвитку.

Скеровуючий вплив на розвиток підлітка може бути ефективним лише тоді, коли він узгоджений із внутрішніми властивостями цієї системи, тобто є резонансним. Проте 
система ідеалів підлітка і системи цінностей, що функціонують у суспільстві, в умовах несталої культурно-історичної епохи постмодернізму можуть не співпадати, що відображає суперечність двох особистісних підсистем: вітального (функціонального) «Я» та ціннісної орієнтації особистості, аксіологічного «Я» (О. Москаленко, В. Сержантов). У зв'язку із цим свідомість підлітка противиться визнанню реальних суспільно-значущих цілей та очікуваних результатів діяльності, і замість них у створюваній «офіційній версії» особистісного становлення виступають цілі, що суперечать особистісній програмі, але пов'язані із формально визнаними індивідом позитивними цінностями суспільства. Подібне мотивування дозволяє людині долучатися до виконання певного виду діяльності без усвідомлення іiї смислової сутності і суспільної значущості й зумовлює суперечливий характер психічного розвитку особистості у період дорослішання [8, с. 40].

Прагнення до підвищення самооцінки в умовах, коли людина вільна у виборі ступеня трудності чергової дії, призводить до конфлікту двох тенденцій - тенденції підвищити домагання, щоб отримати максимальний успіх, і тенденції понизити їх, щоб уникнути невдачі. Переживання успіху (або неуспіху), яке виникає внаслідок досягнення (або недосягнення) рівня домагань, тягне за собою зміщення рівня домагань в сферу більш важчих завдань (або більш легших). Зниження трудності обраної цілі після успіху або ж ії підвищення після невдачі (атипова зміна рівня домагань) вказують на нереалістичний рівень домагань або неадекватну самооцінку [4, с. 417].

В психологічній енциклопедії [7, с. 302] зазначається, що за характером спрямованості розрізняють частковий і загальний рівень домагань особистості. Частковий рівень домагань особистості пов'язують із досягненнями у певних видах діяльності (навчанні, спорті тощо). Він грунтується на оцінюванні особистістю своїх можливостей в окремих видах діяльності. Загальний рівень домагань особистості охоплює кілька аспектів життєдіяльності людини, зокрема ті, в яких найповніше розкриваються ії інтелектуальні і моральні якості. Він спирається на загальну оцінку людиною себе як особистості.

У своїх дослідженнях Н. Токарева зазначає, що сучасні тенденції трансформації сутності людини пов'язані, безумовно, з появою нового покоління молоді, становлення якого відбувається на фоні докорінних суспільно-цивілізаційних зрушень, зокрема, в умовах зміни способів впливу соціального на розвиток особистості, трансформації традиційних механізмів соціальної ідентифікації та форм ії становлення. В силу своїх вікових особливостей підлітки та юнаки (отроцтво в цілому як вікова та соціальна група) найбільш гостро реагують на еволюцію соціокультурного буття, набуваючи поступово нових якісних характеристик [8, с. 51].

Формулювання цілей статті. 3 огляду на вищезазначене мета дослідження здійснити діагностику: 1) самооцінки і рівня домагань та виявити ступінь розходження між цими показниками (за методикою Дембо-Рубінштейн); 2) виявити рівні розвитку рис особистості дітей на межі четвертої і п’ятої стадії психосоціального розвитку (за Е. Еріксоном) в процесі психосоціального розвитку; 3) на основі отриманих результатів проаналізувати співвідношення рівнів дитячої та інституційної вітальностей, які можуть визначати психосоціальний баланс в суспільстві, від якого залежать стійкість соціальної системи і траєкторія iї розвитку.

Виклад основного матеріалу. Для виявлення рівнів розвитку рис особистості дітей в процесі психосоціального розвитку на базових стадіях епігенетичного циклу застосовано методику діагностики самооцінки Дембо-Рубінштейн. В дослідженні брали участь діти 10-11 річного віку (учні 4-5 класів) м. Тернополя (ЗОШ I-III ступенів № 13 імені Андрія Юркевича, 4 А та 4 Б класи, 52 учні), («ЗОШ I-III ступенів-економічний ліцей № 9 імені Іванни Блажкевич», 5 А та 5 Б класи, 54 учні). Всього 106 учнів, 3 них 46 хлопчиків і 60 дівчаток (табл.1).

Таблиия 1

Кількісні показники респондентів

\begin{tabular}{|c|c|c|c|}
\hline Респонденти & хлопчики & дівчатка & Всього \\
\hline 3ОШ № 9 & 24 & 30 & $\mathbf{5 4}$ \\
\hline
\end{tabular}




\begin{tabular}{|l|c|c|c|}
\hline ЗОШ № 13 & 22 & 30 & $\mathbf{5 2}$ \\
\hline Всього & 46 & 60 & $\mathbf{1 0 6}$ \\
\hline
\end{tabular}

Методика діагностика самооцінки Дембо-Рубінштейн в модифікації А. Парафіян [2] заснована на безпосередньому оцінюванні школярами особистих якостей, таких як здоров'я, здібності, характер, впевненість у собі тощо. Їм пропонується на вертикальних лініях позначити певними знаками рівень розвитку у них цих якостей (показник самооцінки) і рівень домагань, тобто рівень розвитку цих же якостей, який би задовільняв їх.

Людина, як представник Homo Sapiens, може оцінювати свої здібності, можливості, характер, впевненість у собі тощо. Рівень розвитку кожної якості людської особистості можна умовно зобразити вертикальною лінією, нижня точка якої символізуватиме найнижчий розвиток, а верхня - найвищий.

Після проведення методики ми 1) визначали за кожною шкалою: а) рівень домагань - відстань в мм від нижньої точки шкали («Про») до знаку «х»; б) висоту самооцінки - від «0» до знаку «-»; в) значення розбіжності між рівнем домагань і самооцінкою - відстань від знаку «х» до знаку «-», якщо рівень домагань нижче самооцінки, він виражається негативним числом; 2) розраховували середню величину кожного показника за всіма шкалами.

Проаналізуємо результати дослідження, які подані в табл. 2.

Таблиия 2

Рангування показників самооцінки та рівня домагань за методикою Дембо-Рубінштейн

\begin{tabular}{|c|c|c|c|c|c|c|c|c|}
\hline \multirow{2}{*}{ 全 } & \multicolumn{4}{|c|}{$\begin{array}{r}\text { ЗОШ I-III ступенів № } 13 \\
\text { імені Андрія Юркевича }\end{array}$} & \multicolumn{4}{|c|}{$\begin{array}{c}\text { ЗОШ І-ІІІ ступенів-економічний ліцей № } 9 \\
\text { імені Іванни Блажкевич }\end{array}$} \\
\hline & $\begin{array}{c}\text { Рівень } \\
\text { домагань }\end{array}$ & $\begin{array}{l}\text { Показ- } \\
\text { ник }\end{array}$ & $\begin{array}{c}\text { Висота } \\
\text { самооцінки }\end{array}$ & $\begin{array}{c}\text { Показ- } \\
\text { ник }\end{array}$ & $\begin{array}{c}\text { Рівень } \\
\text { домагань }\end{array}$ & $\begin{array}{l}\text { Показ- } \\
\text { ник }\end{array}$ & $\begin{array}{c}\text { Висота } \\
\text { самооцінки }\end{array}$ & $\begin{array}{c}\text { Показ- } \\
\text { ник }\end{array}$ \\
\hline 1 & Здоров’я & 98,4 & Здоров’я & 90,9 & Зовнішність & 96,5 & \begin{tabular}{|l|} 
Умілі \\
ручки
\end{tabular} & 82,85 \\
\hline 2 & Зовнішність & 94,95 & Зовнішність & 86,9 & Здоров'я & 95,76 & Здоров'я & 77,55 \\
\hline 3 & $\begin{array}{l}\text { Умілі } \\
\text { ручки }\end{array}$ & 92,65 & Характер & 80,35 & Умілі ручки & 95,1 & Зовнішність & 76,72 \\
\hline 4 & $\begin{array}{l}\text { Розум, } \\
\text { здібності }\end{array}$ & 92,2 & Умілі ручки & 78,75 & $\begin{array}{l}\text { Впевненість у } \\
\text { собі }\end{array}$ & 95,1 & $\begin{array}{l}\text { Впевненість } \\
\text { у собі }\end{array}$ & 69,1 \\
\hline 5 & $\begin{array}{l}\text { Авторитет в } \\
\text { однолітків }\end{array}$ & 91,4 & $\begin{array}{l}\text { Розум, } \\
\text { здібності }\end{array}$ & 75,5 & Характер & 92,65 & $\begin{array}{l}\text { Авторитет в } \\
\text { однолітків }\end{array}$ & 68,55 \\
\hline 6 & $\begin{array}{l}\text { Впевненість } \\
\text { у собі }\end{array}$ & 91,15 & $\begin{array}{l}\text { Авторитет в } \\
\text { однолітків }\end{array}$ & 75,1 & $\begin{array}{l}\text { Розум, } \\
\text { здібності }\end{array}$ & 92,47 & $\begin{array}{l}\text { Розум, } \\
\text { здібності }\end{array}$ & 68,37 \\
\hline 7 & Характер & 90,35 & $\begin{array}{l}\text { Впевненість у } \\
\text { собі }\end{array}$ & 73,4 & $\begin{array}{l}\text { Авторитет } \\
\text { в однолітків }\end{array}$ & 90,65 & Характер & 67,8 \\
\hline
\end{tabular}

Згідно методики діагностики висота самооцінки, визначалась кількістю балів від 45 до 74 («середня» і «висока» самооцінка) засвідчують реалістичну (адекватну) самооцінку. Кількість балів від 75 до 100 і вище свідчить про завищену самооцінку і вказує на певні відхилення у формуванні особистості. Завищена самооцінка може підтверджувати особистісну незрілість, невміння правильно оцінити результати своєї діяльності, порівнювати себе з іншими; така самооцінка може вказувати на істотні спотворення у формуванні особистості - «закритості для досвіду», нечутливості до своїх помилок, невдач, зауважень та оцінок оточуючих. Кількість балів нижче 45 вказує на занижену самооцінку (недооцінку себе) і свідчить про крайнє неблагополуччя в розвитку особистості. Ці учні складають «групу ризику», їх, як правило, мало. За низькою самооцінкою можуть ховатися два абсолютно різних психологічних явища: справжня невпевненість в собі і «захисне спрямування», коли декларування (самому собі) власного невміння, відсутність здібностей тощо дозволяє не докладати жодних зусиль [2]. 
Аналіз даних табл. 2 показує, що в респондентів обох вибірок виявлено нереалістичне, некритичне ставлення до власних можливостей, бо середній показник за вибірками в обох групах перевищує 90 балів. Проте показники висоти самооцінки вже різні в обох вибірках. Зокрема в групі респондентів ЗОШ № 13 виявлено завищену самооцінку в шістьох показниках і тільки за впевненість у собі він займає верхню межу високої самооцінки. Відповідно в учнів школи-ліцею № 9 вже таких високих показників виявлено лише в чотирьох пунктах (впевненість у собі, авторитет в однолітків, розум і здібності, характер (табл. 2). Крім того аналіз рангів групи школярів ЗОШ № 13 виявив, що між рівнем домагань та висотою самооцінки перші два ранги не змінилися (показник здоров'я та зовнішність). В респондентів ЗОШ-ліцею № 9 не змінили своєї порядкової позиції ранги 2, 4, та 6 (здоров'я, впевненість у собі, розум та здібності). 


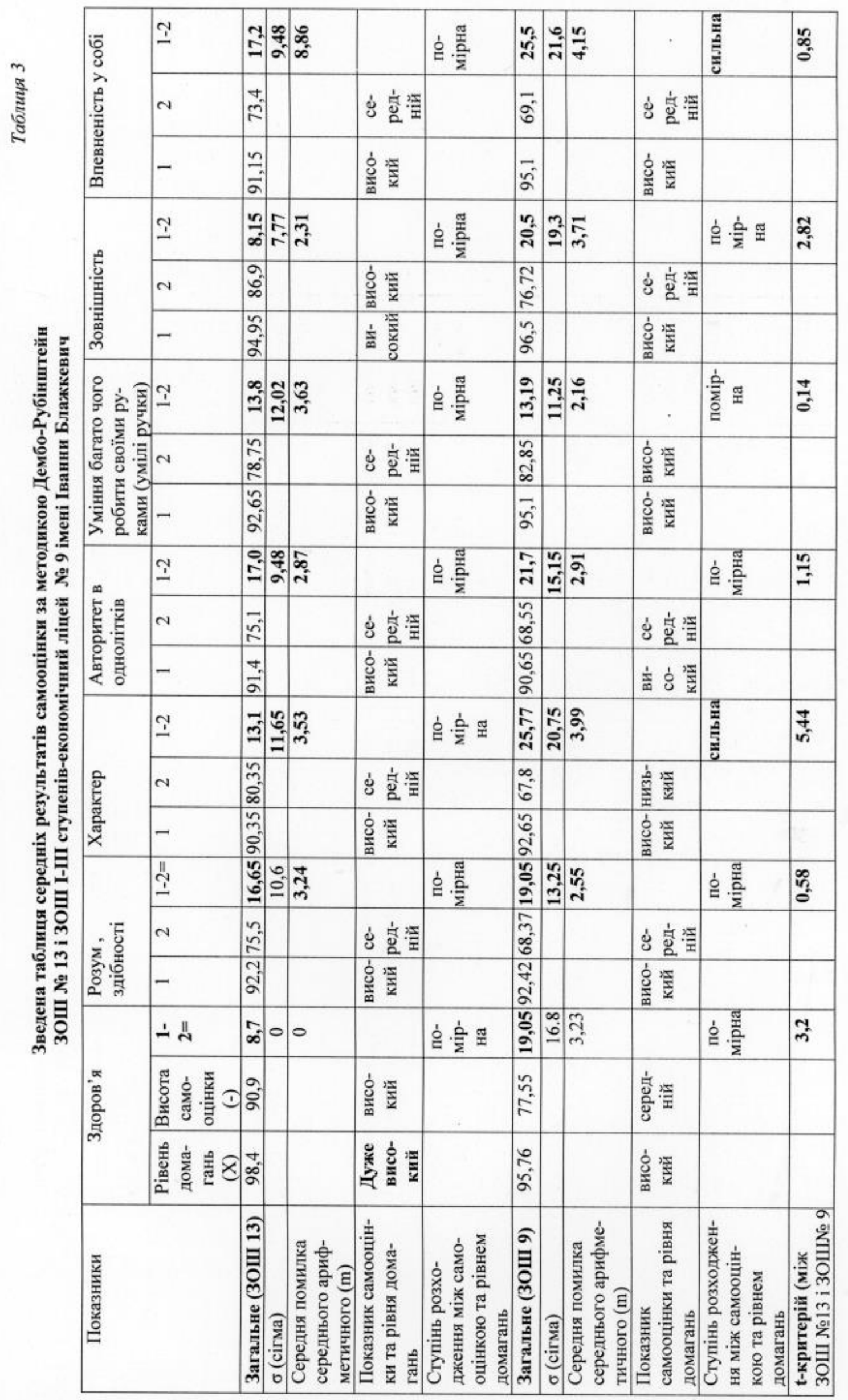


Аналізуючи рівень домагань, ми спиралися на те, що норму, реалістичний рівень домагань, характеризує результат від 60 до 89 балів. Найбільш оптимальний - порівняно високий рівень - від 75 до 89 балів, що підтверджує оптимальне уявлення про свої можливості, та є важливим чинником особистісного розвитку. Результат від 90 до 100 балів, зазвичай, засвідчує нереалістичне, некритичне ставлення дітей до власних можливостей. Результат менше 60 балів вказує на занижений рівень домагань, він - індикатор несприятливого розвитку особистості [6, с. 67].

Для порівняння вибіркових середніх величин і для з'ясування чи відрізняються середні значення статистично достовірно одні від одних, застосовано t-критерій Стьюдента. До того ж виходячи 3 критичного показника t-критерію Стьюдента для заданого числа ступенів свободи та ймовірностей допустимих помилок, рівних $\mathbf{0 , 0 5 ; 0 , 0 1 , ~ я к и и ̆ ~ д л я ~} 106$ чоловік за таблицею [3, с. 39] дорівнює відповідно 1,98 (для 0,05) та 2,63 (для 0,01), відмінностей між самооцінкою в обох групах - не виявлено за такими показниками як: уміння багато чого робити своїми руками (показник 0,14$)$, розум і здібності $(0,58)$, впевненість у собі $(0,85)$ та авторитет в однолітків $(1,18)$. Ці показники $\mathrm{t}$-критерію $\epsilon$ в межах від 0,14 до 1,15. В отриманих результатах самооцінки за показниками зовнішність $(2,82)$, здоров'я $(3,2)$ та характер $(5.44)$ між учнями «ЗОШ-економічного ліцею № 9» та ЗОШ № 13 вже виявлено відмінності (табл. 3). Зауважимо, що в респондентів «ЗОШ-економічний ліцей № 9» виявлено сильну ступінь розходження між самооцінкою та рівнем домагань за двома показниками, а саме: характер та впевненість у собі, де числові вираження рівня домагань $є$ вищими від показників самооцінки.

Висновки. Рівень домагань безумовно залежить від (не)адекватності самооцінки. У поведінці це проявляється у виборі занадто важких або занадто легких цілей, у підвищеній тривожності, невпевненості у своїх силах, тенденції уникати ситуації змагання, некритичності в оцінці досягнутого, помилковості прогнозу тощо.

Вважаємо, що перспективами подальших розвідок даного аспекту є те, що доцільно також продіагностувати у респондентів основні риси особистості за допомогою дитячого варіанту особистісного тесту Кетелла (11 шкал) і порівняти їх за трьома рівнями розвитку (низький, середній та високий). Це дозволить ще більше поповнити банк емпіричних даних про досліджуваний віковий період школярів і спрогнозувати майбутній психосоціальний баланс в суспільстві, від якого залежать стійкість соціальної системи і траєкторія іiі розвитку.

1. Ильин В. А. (2009). Психосоииальная теория как полидисииплинарный подход к анализу социальных прочессов в современном обществе : автореф. дис. ... докт. психол. наук. Москва.

2. Методика діагностики самооцінки Дембо-Рубінштейн. Взято 3: http://psychologis.com.ua/ metodika_diagnostika_samoocenki_dembo-rubinshteyn._modifikaciya_prihozhan.htm.

3. Немов Р.С. (1995). Психология: Учебник. Кн. 3: Экспериментальная педагогическая психология и психодиагностика. Москва: Просвещение: ВЛАДОС.

4. Петровский А. В., Ярошевский М. Г. (Ред.), (1990). Психология. Словарь. Москва : Политиздат.

5. Савчин М. В., Василенко Л. П. (2017). Вікова психологія. Київ : ВЦ Академія.

6. Сіткар В. (2018) Гендерний аспект самооцінки особистих якостей у четвертокласників за методикою Дембо-Рубінштейн. Психологічні виміри розвитку сучасної освіти Украӥни в умовах євроінтеграиії, 19-20 жовтня 2018 p. (с.66-68). Тернопіль, ТНПУ ім. В. Гнатюка.

7. Степанов О. М. (2006). Психологічна енциклопедія. Київ: «Академвидав».

8. Токарева Н. М., Шамне А. В., Макаренко Н. М. (2014). Сучасний підліток у системі психологопедагогічного супроводу : монографія. Кривий Ріг. «Інтерсервіс».

\section{REFERENCES}

1. Ylyn V. A. (2009). Psykhosotsyalnaia teoryia kak polydystsyplynarnbii podkhod k analyzu sotsyalnblkh protsessov v sovremennom obshchestve : avtoref. dys.. dokt. psykhol. nauk. Moskva. (rus).

2. Metodyka diahnostyky samootsinky Dembo-Rubinshtein. Vziato z: http://psychologis.com.ua/ metodika_diagnostika_samoocenki_dembo-rubinshteyn._modifikaciya_prihozhan.htm. (ukr).

3. Nemov R.S. (1995). Psykholohyia: Uchebnyk. Kn. 3: Эksperymentalnaia pedahohycheskaia psykholohyia y psykhodyahnostyka. Moskva: Prosveshchenye: VLADOS. (rus). 
4. Petrovskyi A. V., Yaroshevskyi M. H. (Red.), (1990). Psykholohyia. Slovar. Moskva : Polytyzdat. (rus).

5. Cavchyn M. V., Vasylenko L. P. (2017). Vikova psykholohiia. Kyiv : VTs Akademiia. (ukr).

6. Sitkar V. (2018) Hendernyi aspekt samootsinky osobystykh yakostei u chetvertoklasnykiv za metodykoiu Dembo-Rubinshtein. Psykholohichni vymiry rozvytku suchasnoi osvity Ukrainy v umovakh yevrointehratsii, 19-20 zhovtnia 2018 r. (s.66-68). Ternopil, TNPU im. V. Hnatiuka. (ukr).

7. Stepanov O. M. (2006). Psykholohichna entsyklopediia. Kyiv: «Akademvydav». (ukr).

8. Tokareva N. M., Shamne A. V., Makarenko N. M. (2014). Suchasnyi pidlitok u systemi psykholoho-pedahohichnoho suprovodu : monohrafiia. Kryvyi Rih: «Interservis». (ukr).

\section{Viktor Sitkar \\ DIAGNOSTICS OF THE LEVEL OF ASPIRATION AND SELF-MEMBERSHIP AT THE AGE OF CHILDHOOD AND ADOLESCENTE}

The article states that empirical studies of various aspects of childhood form an opinion on the general background of the social situation, which affects the development of personality in adolescence. Diagnosis of the level of aspiration and self-esteem among pupils transition between childhood and adolescence completed the bank of scientific data on a complex system of personal formation, which has an unlimited plurality of ways of development in the direction of gradual expansion of individual's capabilities. Based on the existing potential, the psychosocial balance in society is determined, on which the stability of the social system and the trajectory of its development depend in the future.

The study found that both respondents showed unrealistic, uncritical attitudes toward their own opportunities, since their average score exceeds 90 points. However, self-esteem levels are already different in both observed groups.

In particular, according to the Student's criteria, no distinction was made between self-esteem for such indicators as: the ability to do a lot with their own hands (index 0.14), intelligence and ability (0.58), self-confidence (0.85), and authority among adolescents (1.18). In the obtained results of self-esteem in terms of appearance (2.82), health (3.2) and character (5.44) between pupils of secondary school number 9 and secondary school number 13 already there are differences, because they exceed the table t-criterion, which is equal, respectively 1.98 (for 0.05) and 2.63 (for 0.01). The respondents of the secondary school № 9 revealed a strong degree of distinction between self-esteem and level of claims in two indicators, namely: the nature and self-confidence, where numerical expressions of the level of claims are higher than self-esteem. This is explained by the fact that the social and functional conditions of the schools in which the students' educational and other activities take place are different.

Keywords: childhood, adolescents, self-esteem, level of aspirations, personality, diagnostics, development. 